
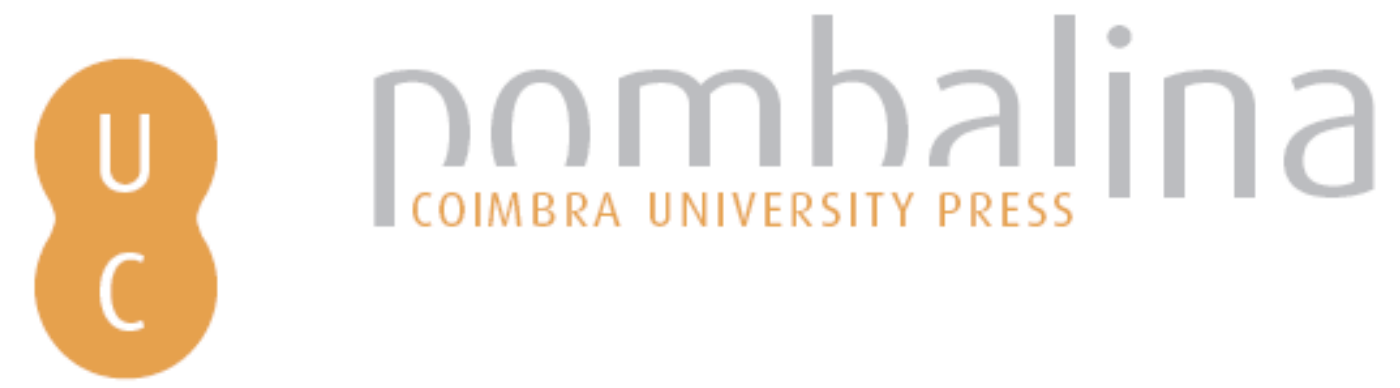

\title{
Teatro jesuítico e estética barroca: o testemunho dum drama truncado, anónimo e sem título (BPE, cod. CVIII /2-7, 61r-85v)
}

Autor(es): $\quad$ Barbosa, Manuel José de Sousa

Publicado por: Imprensa da Universidade de Coimbra

URL

persistente: URI:http://hdl.handle.net/10316.2/32331

DOI: DOl:http://dx.doi.org/10.14195/978-989-26-0482-4_6

Accessed : $\quad$ 26-Apr-2023 12:23:14

A navegação consulta e descarregamento dos títulos inseridos nas Bibliotecas Digitais UC Digitalis, UC Pombalina e UC Impactum, pressupõem a aceitação plena e sem reservas dos Termos e Condições de Uso destas Bibliotecas Digitais, disponíveis em https://digitalis.uc.pt/pt-pt/termos.

Conforme exposto nos referidos Termos e Condições de Uso, o descarregamento de títulos de acesso restrito requer uma licença válida de autorização devendo o utilizador aceder ao(s) documento(s) a partir de um endereço de IP da instituição detentora da supramencionada licença.

Ao utilizador é apenas permitido o descarregamento para uso pessoal, pelo que o emprego do(s) título(s) descarregado(s) para outro fim, designadamente comercial, carece de autorização do respetivo autor ou editor da obra.

Na medida em que todas as obras da UC Digitalis se encontram protegidas pelo Código do Direito de Autor e Direitos Conexos e demais legislação aplicável, toda a cópia, parcial ou total, deste documento, nos casos em que é legalmente admitida, deverá conter ou fazer-se acompanhar por este aviso.

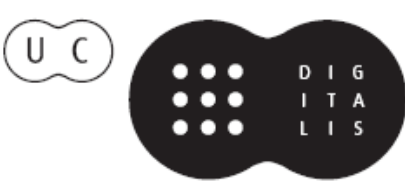


Sebastiāo Tavares de Pinho

Coordenação

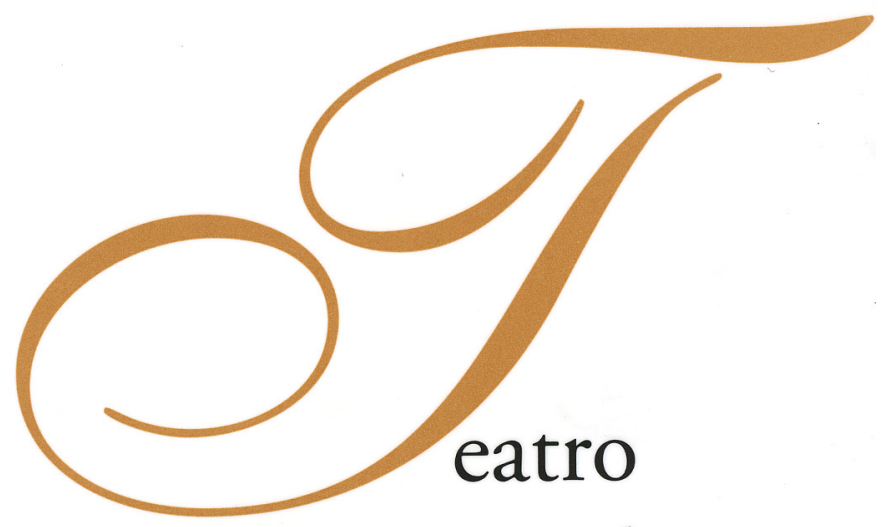

Neolatino em Portugal

no Contexto da Europa

450 Anos

de Diogo de Teive

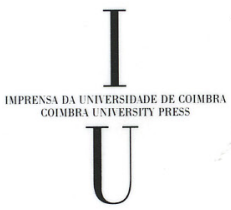

- COIMBRA 2006 
(Página deixada propositadamente em branco) 
C

U

M

E

$\mathrm{N}$

T

0

S

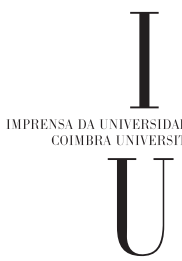




\section{COORDENAÇÃO EDITORIAL}

Imprensa da Universidade de Coimbra

URL: http//www.imp.uc.pt

\section{CONCEPÇÃo GRÁFICA}

António Barros

PRÉ-IMPRESSÃo

António Resende

Imprensa da Universidade de Coimbra

EXECUÇÃo GRÁFICA

SerSilito - Maia

ISBN

$972-8704-75-5$

DEPÓSITO LEGAL

(C) Junho 2006, Imprensa da Universidade de Coimbra

OBRA PUBLICADA COM O FINANCIAMENTO DE:

Centro de Estudos Clássicos e Humanísticos

FCT Fundação para a Ciência e a Tecnologia

MINISTÉRIO DA CIÊNCIA, TECNOLOGIA E ENSINO SUPERIOR Portugal

OBRA PUBLICADA COM O APOIO DE:

FCT: Fundação para a Ciência e Tecnologia • Ministério da Ciência e do Ensino Superior Apoio do Programa Operacional para a Ciência, Tecnologia, Inovação do III Quadro Comunitário de Apoio 
O TEATRO NeOlatino EM PORTUGal NO CONTEXTO DA EUROPA

450 AnOs DE DIOGO DE TEIVE 
(Página deixada propositadamente em branco) 
Manuel José de Sousa Barbosa

Universidade de Lisboa

\author{
TEATRO JESUÍTICO E ESTÉTICA BARROCA: \\ O TESTEMUNHO DUM DRAMA TRUNCADO, \\ ANÓNIMO E SEM TÍTULO (BPE, COD. CVIII/2-7, 61R-85V)
}

Sobre este drama anónimo, truncado e sem título tive já ocasião de me pronunciar uma primeira vez em artigo publicado na revista Euphrosyne onde formulei várias hipóteses sobre a sua autoria e apresentei, em apêndice, um resumo da acção dramática por cenas e a transcrição dos coros. ${ }^{(1)}$ O meu interesse por este texto tem a ver com a questão bem espinhosa do repertório do teatro jesuítico, tão difícil de estabelecer, já que são muitas as notícias nas litterae dos Jesuítas sobre representações teatrais e escassos os textos disponíveis que, nem sempre, como é o caso, permitem estabelecer um elo inequívoco com tais notícias. Não são muitos os casos em que tais repertórios remetam com segurança para os textos. Estes não se conservaram em muitíssimos casos e, dos que se conservaram, nem sempre possuímos um conjunto de referências que salvaguardem o carácter inequívoco da associação notícia - texto.

Esta minha comunicação pretende, pois, antes de mais, apresentar-se como uma achega para o enriquecimento do repertório do teatro jesuítico,

(1) Cf. "Luzes e mistérios no teatro jesuítico. BPE, cod. CVIII/2-7, fls. 61r-85v: o Nabuchodonosor de Stephanus Tuccius? Interpelações de um texto truncado", Euphrosyne 31 (2003), pp. 415-426. Nas citações de versos desta peça, indicaremos os actos em numeração romana e as cenas em árabe. Tais indicações remetem para a edição provisória do texto por nós elaborada. 
projectando luz sobre um drama que, pela situação codicológica do seu texto, se afigura inequivocamente jesuítico, presumivelmente do último quartel do século XVI e provavelmente representado no colégio de Évora. O facto de o texto desta tragédia (ou tragicomédia), aparecer inicialmente truncado terá desviado dele atenções que, é minha convicção, lhe são merecidas, atenções essas que, quem sabe se indevidamente, se centraram noutro drama, este de texto integral e de tema similar, ostentando como título Tragicomoedia Nabucodonosor, inserto noutro códice igualmente da Biblioteca de Évora, de idêntica génese jesuítica. (2)

No artigo da Euphrosyne acima referido expliquei por que razão algumas afirmações de C.-H. Frèches a propósito deste Nabucodonosor de texto integral me pareciam mais susceptíveis de se aplicarem a este drama de texto truncado que, tudo o leva a crer, possuiria título idêntico. Ou seja: o drama analisado por Frèches pode não ter sido o representado em Évora no ano de 1576 , perante o Cardeal D. Henrique, num espectáculo de cinco horas, mas sim este, de que hoje vos vou falar; e o que o estudioso francês do teatro neolatino em Portugal afirmava quanto a «não ser impossível estar-se perante o Nabucodonosor desaparecido de Stefano Tucci», creio eu que poderá afirmar-se igualmente deste drama truncado que até hoje passou praticamente ignorado. (3)

Pretendo hoje com esta minha comunicação dar continuidade à apresentação desta peça teatral duma forma mais profunda, em ordem a evidenciar a estética subjacente a uma imitatio que conferiu à fábula dramática o seu aspecto singular. Não sou especialista em estética do barroco, como o título desta minha comunicação poderá fazer pensar. Tenho do barroco a ideia geral de movimento artístico que, numa ruptura com a estética renascentista, quebra equilíbrios formais e funcionais na abordagem de determinados temas, segundo uma lógica do excesso na representação da realidade, lógica

(2) O códice BPE, cod. CVIII/2-8, fls. 35-68, de características materiais gémeas, reúne igualmente composições em prosa e verso oriundas dos actos académicos da "Academia Eborensi", como se pode ler na lombada de ambos. Cf. Ibid., pp. 416-417.

(3) Cf. Ibid., pp. 422-423. 
essa que confere aos elementos significantes uma forte preponderância, num jogo complicado mas significativo da intencionalidade do artista.

O conhecimento que fui adquirindo gradualmente deste drama, concomitante à leitura e progressiva fixação do seu texto manuscrito, com tradução incluída, convenceu-me de que valia a pena resgatar das trevas e colocar com validade a plena luz este texto ignorado. Os versos iniciais que faltam, ${ }^{(4)}$ felizmente não invalidam a formação duma apreciação global desta dramatização do Livro de Daniel, capítulos 2, 3 e 4. As primeiras impressões recolhidas logo me mostraram que a singularidade desta dramatização se alimentava de toda uma retórica que, não apenas ao nível da elocutio, mas também ao nível da encenação, com toda a sua carga de sonoridades e de visual, veiculava uma ars persuadendi por demais denunciadora dos seus objectivos finais. Talvez seja mais correcto falar, neste caso, de estética barroca de génese jesuítica, no sentido de que o artefacto denuncia a conhecida estratégia de eficácia característica dos seguidores de S. Inácio, ao serviço de propósitos concretos, inseridos em tempo e lugar bem estudados. ${ }^{(5)}$

A abordagem dramática deste passo bíblico, tão multiplicada desde a Idade Média, na Renascença e, concretamente, no teatro jesuítico, da forma como surge aqui concretizada denota a concepção medieval que levava à apreensão dos acontecimentos históricos como representações das forças da consciência, traduzindo a infindável luta entre bem e mal, entre virtude e vício. É esta ideia de embate eterno entre as referidas forças antagónicas que parece estar na base da demarcação bem patente em cena dos dois campos por onde se repartem as personagens de extracção bíblica a que se associam, de acordo com a situação dramática, as de índole alegórica que dão expressão plástica a esse embate de índole psicológica. Assim, o campo das forças do mal (uitia) que manipulam Nabucodonosor surge comandado por Soberba, a senhora do mundo, assessorada pelo príncipe de

(4) Eles conteriam certamente o prólogo e uma ou duas cenas do primeiro acto, de que nos resta apenas uma.

(5) Contra a ideia simplificadora de se chamar à arte jesuítica arte barroca, cf. VICTOR-L. TAPIÉ, O Barroco, trad. de Armando Ribeiro Pinto, Editora Cultrix, Universidade de São Paulo, p. 18. 
seu reino, designado em latim de Cupido e representado na conhecida figura duma criança alada, munida de arco e setas, mas esvaziado de conotações eróticas. As suas setas não levam a Nabucodonosor o fogo do amor, mas o da ambição desmedida. Por isso, optamos por traduzir a designação latina desta personagem por "Ambição». A ela junta-se também a Perfídia.

No campo oposto, ao profeta Daniel e aos três jovens hebreus associar-se-ão as alegorias da Fé, da Esperança e da Constância. As restantes personagens, a saber, os sátrapas, Vilmerodaque e os mensageiros, integram-se com verosimilhança neste quadro dramático marcado pelo antagonismo que referimos atrás, em consonância com o relato bíblico.

\section{A unidade da acção dramática}

Estamos longe aqui do propugnado pela reflexão dos humanistas em torno da poética de Aristóteles, reflexão essa acompanhada da emergência da chamada tragédia regular, assente na observância da lei das três unidades, de que se aponta geralmente como primeiro exemplo a Sofonisba de Giovanni Giorgio Trissino. Pelo contrário, assistimos neste Nabucodonosor a uma pluralidade de acções que, a nosso ver, se interligam e evoluem segundo a dinâmica de dar expressão dramática à ideia de humilhação dos soberbos e, concomitantemente, à de afirmação incontestável do poder divino. A prioridade desta dinâmica explica a sucessão em palco de um conjunto de cenas que mais propriamente designaríamos de quadros justapostos, duma forma que, salvaguardando embora a fidelidade ao passo bíblico, não se move por preocupações de verosimilhança de tempos e lugares.

A acção dramática, no seu todo, apresenta-se polarizada em dois momentos bem diferenciados, assentes na ideia de triunfo. Assistimos primeiramente a uma tentativa de triunfo, conduzida por Soberba, a senhora do mundo ("domina mundi»), como a tratam os seus servidores, frustrada por não ser ainda senhora de Nabucodonosor, para merecer em pleno tal tratamento 
(Acto II, cena 1). Este triunfo da Soberba será incompleto e efémero. Ela apoderar-se-á da mente de Nabucodonosor, mas serão vãos os seus esforços para esmagar Daniel, o seu principal obstáculo. O acto III, com a provação dos três jovens salvos miraculosamente da fornalha, marca o ponto culminante da tensão dramática, se é que se pode falar nesta peça em verdadeira tensão dramática. Soberba realizou efectivamente o seu propósito de fazer Nabucodonosor entregar seu coração à Ambição, mas a salvação miraculosa dos três jovens é já o presságio do triunfo final da Fé no acto V. Este triunfo final da Fé, em que o poder de Deus se afirma esmagadoramente, dá-se após a humilhação extrema de Nabucodonosor que, na sua bybris sacrílega, se elevara até às nuvens, pretendendo tratamento divino. Tal humilhação marca o acto IV onde o castigo do monarca, com o seu exílio do poder durante sete anos, transformado em boi e alimentando-se na companhia de outras alimárias, ilustra as consequências da atitude de orgulho desmedido do monarca e faz reflectir sobre o uso do poder, a questão da sucessão e os perigos antevistos numa situação de vazio de poder.

\section{A figura de Nabucodonosor}

Neste jogo de contrastes com que o dramaturgo caracterizou a sua peça, a figura de Nabucodonosor surge-nos incontornável numa análise sob esta perspectiva. O claro e o escuro demarcam-se aí com nitidez, no que respeita à sua atitude mental antes e após o castigo. Primeiramente temos o tipo de tirano pagão, marcado por atitudes de orgulho, de violência e de impiedade; deparamos depois com um modelo de príncipe enaltecido como sábio e submisso a Deus, sem apego ao poder.

A primeira face de Nabucodonosor enquanto modelo de tirano pagão é-nos dada em grande parte em cenas onde a alegoria está presente. O seu fascínio pela glória surge-nos testemunhado na cena 3 do acto III onde, após dar um beijo à Ambição, exclama: "Oh! Quão doce é o sabor da glória» 
e pede ao jovem que personifica tal vício que lhe permita usufruir muitas vezes de abraço tão doce. ${ }^{(6)}$ Fica regalado com a promessa de tal concessão. Na despedida, Ambição refere-se-lhe como «a ilustração perfeita do seu poder». (7) Outro traço caracterizador do tirano é um excesso de confiança que invade a área do sacrílego. Não acredita que a invejosa fortuna possa contaminar a sua alegria com algum infortúnio. A confiança cega no carácter inabalável da sua felicidade pessoal vai ao ponto de confessar ser também ele um deus. A contemplação do esplendor inigualável do seu poder fá-lo sentir-se o mais ditoso de todos os reis, enumerando, com intuitos comparativos, as limitações dos outros monarcas. Auto-elogia-se numa série de interrogações onde passa em revista os seus grandiosos feitos, sem evitar a blasfémia:

"Mais: ousaria algum deus fazer-me frente?»(8)

Mas na mesma cena em que Nabucodonosor se vangloria da sua glória e poder excepcional, em que confessa sem pejo gostar de fazer-se representar abraçado a todo o globo terrestre, ${ }^{(9)}$ soará a voz do Anjo, plena de autoridade ("Nem uma palavra enquanto falo»), ${ }^{(10)}$ para lhe anunciar o castigo de sete anos de vida errante pelos campos como um boi, castigo que lhe fará saber que é Deus quem reina. Do estado deplorável a que se viu reduzido são múltiplas as referências trazidas à cena, nas intervenções dos dois mensageiros e do próprio filho, Vilmerodaque, que lamenta, inconsolável, a imundície e a sordidez do pai.

Radicalmente diferentes são as novas atitudes do Nabucodonosor convertido, regressado do castigo. Antes de mais, refira-se a submissão a Deus.

(6) «Nabuc. O iucundum gloriae gustum diem / O laetum, dulcem o nimium, et felicem diem! / Liceat amplexu saepius o puer tuo / Tam dulci perfrui.» - III, 2, 805-8

(7) «O felix nostri maximum imperii decus.» - loc. cit., 808.

(8) «Obstare mihi quin ullus auderet deus," - IV, 2, 1163.

(9) "Sic ego me mecum soleo saepe fingere / Totam tenentem machinam amplexu meo." - IV, 2, 1172-3

(10) Nabuc. Miserere, Ang. Nullum, dum loquor uerbum, sile» - IV, 2, 1202. 
Se Daniel the diz que são ordens de Deus, logo ele declara obedecer de boamente ${ }^{(11)}$; realce-se igualmente a profunda renitência em reassumir o poder e que está na base desta viva altercação com Daniel:

\begin{abstract}
Daniel - Recusas fazer o que ordena o Deus supremo?
Nabuco - Recuso fazer o que o Deus supremo proíbe.

Daniel - O Deus celeste ordena que assumas o poder.

Nabuco - O mesmo Deus proíbe o poder aos soberbos.

Daniel - Não governará orgulhosamente quem foi precipitado do alto do trono por causa do seu orgulho.

Nabuco - Esta péssima desgraça acompanha todos os orgulhosos. Expulsos do poder, ostentam um ar humilde, mas se regressarem ao poder, ficam mais orgulhosos do que antes. $^{(12)}$
\end{abstract}

Nabucodonosor cederá, finalmente, confiante de que a mão poderosa de Deus o segurará, para que não resvale dessas receadas alturas. A esta renitência em assumir o poder, acrescente-se, por fim, o desprezo pelo fausto que lhe está associado. Para Nabucodonosor, que agora odeia o ceptro, a púrpura, o trono e tudo o que se lhe associa, aqueles trajes sujos e grosseiros que ostenta em cena dão-lhe a garantia do perdão do seu crime. Acabará por abandoná-los, não tanto por pressão do filho mas porque, como o informa Daniel, "Deos o ordena». Antes porém que esta difícil renúncia se efective, o dramaturgo, num exagero de encenação, coloca Nabucodonosor em cena abraçado aos seus imundos andrajos, chorando em saudosa despedida, com palavras que decalcam as da desesperada Dido, no canto IV da Eneida, sobre as reluzentes armas do guerreiro troiano, já fora do seu alcance para sempre:

(11) «Dan. Huc te reduci caelitum numen iubet. / Nab. Iubet? Libenter subiicio imperio caput.» - V, 2, 1603-4

(12) «Dan. Numen recusas facere quod summum imperat? / Nab. Numen recuso facere quod summum uetat. / Dan. Caeleste, sceptrum capias, Numen imperat. / Nab. Idem superbum, Numen imperium uetat. / Dan. Non imperabit tumide quem semel tumor / Ex alto Regni praecipitem solio dedit. / Nab. Hoc tumidos sequitur maximum cunctos malum / E Regno pulsi, abiectam ceruicem gerunt / Hi Regnum redeant peius quam prius tument.» - V, 2, 1612-1620. 
Doces despojos enquanto o destino e um deus o permitia. Ah! Como seria feliz, feliz por demais, se a minha vida tivesse terminado seus dias no meio dos bosques, para não empunhar, ao invés, os ceptros enganadores, nem ver os reinos perigosos. Porque vos abandonei, ingrato que fui, ó lugares ocultos? Porque vos abandonei, ó agradáveis covis das feras? Como me seria mais doce levar uma vida discreta entre vós, ignorado do mundo e quando, por fim, os dardos da morte me ferissem, sepultar então meu pobre corpo em terra humilde, do que ter de empunhar o ceptro e ostentar a cabeça orlada de pérolas. Ó morte que tardas em chegar, porque me reservas esta sorte?(13)

\section{Os diálogos}

Outra instância do drama onde avulta o contraste, e aqui com uma funcionalidade muito própria do docere, são determinados diálogos conduzidos segundo o esquema típico da disputatio, contrapondo geralmente duas personagens, numa sucessão de réplicas marcadas por um paralelismo antitético, em que um dos interlocutores vai dando resposta às sucessivas e renovadas objecções do outro, promovendo ambos deste modo o esclarecimento da questão em debate. Um caso exemplar é o da cena dos dois sátrapas (IV, 5) que, ao longo de setenta versos, aproximadamente, comentam a situação de vazio de poder gerada com o exílio de Nabucodonosor, incertos quanto ao futuro próximo e receosos da sua sorte nesta rotação da fortuna que colocará no poder Vilmerodaque, filho de Nabucodonosor. Continuarão ou não a beneficiar do favor real? O tipo de resposta prudente e sentenciosa de um deles soa como um sinal de sabedoria acrescida donde manam as lições a reter. Veja-se o seguinte extracto do diálogo em que se conjectura sobre a futura atitude de Vilmerodaque, quando assumir as rédeas do poder:

(13) Dulces exuuiae dum fata, deusque sinebat / Felix ah! Nimium felix si uita fuisset / In syluis finita mihi, ne perfida rursus / Sceptra manu gererem, neque lubrica regna uiderem. / Cur uos ah latebrae, cur ah grata antra ferarum / Deserui ingratus? Quanto mihi dulcius esset / In uobis tacitam ignotum traducere uitam / Et tandem cum me fixissent spicula mortis / Sub uili miserum deponere cespite corpus / Quam sceptrum gestare manu quam tempora gemmis. / Ah mors sera nimis quid me haec in fata reseruas? - V, 2, 1671-1681. 
Sátrapa 1 - Acreditas que a dor e as lágrimas possam durar muito tempo? Mal se veja sentado no trono real, cheio de orgulho, com a cabeça enfeitada de ouro, esquecerá o pai, promoverá outros e banirá estes da sua antiga posição.

Sátrapa 2 - Não venerará o nome do pai ausente?

Sátrapa 1 - Uma vez chegados ao poder, o nome do pai é vil para os reis.

Sátrapa 2 - E não receará gozar da fama de filho ingrato?

Sátrapa 1 - Os que reinam para si próprios pensam que tudo lhes é lícito.

Sátrapa 2 - Temerá a divindade, essa temível divindade, a mando da qual o pai se arrasta expulso do poder.

Sátrapa 1 - O orgulhoso nunca aprende com o exemplo alheio.

Sátrapa 2 - Mas ele não ficará orgulhoso.

Sátrapa 1 - Não empunhará o ceptro por muito tempo.

Sátrapa 2 - Mas ele recusa verdadeiramente assumir a condição real e não deseja reinar com o pai expulso. Odeia o ceptro, a púrpura, o orgulho.

Sátrapa 1 - Finge odiar.

Sátrapa 2 - Ou antes, tu é que receias demasiado.

Sátrapa 1 - É insensato viver na corte sem experimentar o medo.

Sátrapa 2 - Não quem se sente bafejado pelo favor benevolente dos príncipes.

Sátrapa 1 - Pelo contrário, para esse é demasiado enganador o favor dos príncipes.

Sátrapa 2 - Certo é o amor posto à prova durante muito tempo.

Sátrapa 1 - Muitas vezes, o que durante muito tempo foi posto à prova num instante se esvai.

Sátrapa 2 - Que resolução aconselhas então que tomemos neste momento?

Sátrapa 1 - Armemo-nos de coragem para a incerteza da situação. ${ }^{(14)}$

(14) «Satrapa An tu dolorem credis, et lachrymas Diu / Durare posse? Regio ut semel throno / Sceptro superbus sederit, fuluo caput / Ornatus auro, pectore expellet patrem, / Attollet illos, pristino hos trudet gradu / Alius Annon parentis nomen absentis colet / Satrapa Post sceptra uile est regibus nomen patris. / Alius Annon timebit filii ingrati notam? / Satrapa Licere credunt cuncta, qui regnant sibi. / Alius Numen timebit, cuius imperio parens / (Numen timendum) pulsus e regno iacet. / Satrapa Alterius nunquam tumidus exemplo sapit. / Alius At non tumebit. Satrapa Non feret sceptrum diu. / Alius At ille uero capere regalem manu / Virgam recusat, patre nec pulso cupit / Regnare, sceptrum purpuram, fastus odit.

Satrapa Odisse fingit. Alius Imo tu nimium times. / Satrapa Stultum est in aula uiuere expertem metus. / Alius Non cui benignus principum aspirat fauor. / Satrapa Huic imo fallax 
Também para inteirar a plateia do aspecto horrendo de Nabucodonosor no seu exílio de vida selvagem, recorre o dramaturgo a dois mensageiros cujas falas, alternando-se em estilo bem diferenciado, remetem para dois estados de espírito: de um lado, ou seja, do lado de quem viu, há um sentimento de horror, de completo transtorno mental, de desnorte e perplexidade sobre o que fazer com notícia tão horrível, se dar ou não ao filho tal notícia sobre o estado lastimável do pai; no outro, que não viu, a serenidade, aliada a uma curiosidade natural de perceber o que se passa. Os dois mensageiros irrompem em cena. O primeiro com falas em tom veemente, tendencialmente ampliadas com frequentes exclamações e interrogações que entrecortam e quase bloqueiam o fluir das informações aguardadas pelo outro. Este limita-se a intervir inicialmente de forma breve e simples, reclamando do outro a continuação do relato interrompido. Inteirado de toda a situação, é então a vez de também ele elevar o tom do discurso para lamentar a condição actual do tirano, evocando, na figura duma apóstrofe a Nabucodonosor, o seu esplendor de outros tempos. A esta apóstrofe associa-se em paralelo outra, pela boca do outro mensageiro, consagrada aos ardis da fortuna. Esta alteração em cena do estado de espírito dum dos mensageiros tem um efeito amplificador, acentuando o carácter inenarrável do conteúdo da notícia sobre o estado deplorável a que desceu Nabucodonosor. Do desnivelamento cognitivo e afectivo que diferenciava inicialmente os dois mensageiros, passou-se agora a uma consonância de posições extensível ao domínio volitivo. Que fazer? Era a pergunta do mensageiro transtornado, de posse duma notícia terrível. A resposta será dada pelo outro, pelo que não viu a crueza dos factos, mas a eles chegou pela narração do companheiro. O seu conselho final vai no sentido de que uma notícia destas não deverá ser de modo nenhum dada ao filho de Nabucodonosor:

- "retira-te e esconde-te até que ele regresse de novo ao seu reino». (15)

principum est nimis fauor. / Alius Diu probatus certus est amor; Satr. Diu / Probata saepe temporis puncto cadunt / Alius Quid ergo nos nunc capere consilii mones? / Satrap. Paremus animos fortis ad dubias uices.» - IV, 5, 1341-1364.

(15) "Alius Abscede, et dum redeat iterum ad regnum, late." - IV, 6, 1458. 


\section{A alegorização como ilustração do combate psicológico}

O assalto da Ambição: Um dos processos mentais ilustrado em cena tem a ver com a cedência de Nabucodonosor à ambição, tema da cena 2 do acto III, que vale a pena passar aqui em revista. O monarca confessa-se seduzido por Ambição, enredado nos seus laços, disposto a segui-la, arde já nas chamas de Ambição, mas ela adverte-o de que isso tem o seu preço, e dita as suas leis. Para a seguir, o tirano terá de as acatar. Terá de perder a vergonha e não sentir pejo de exprimir às claras o que ocultamente deseja, porque a primeira lei da Ambição é não ter vergonha nenhuma; a segunda, não recear nem os homens nem os deuses. (16) Nabucodonosor hesita, num combate interior que funciona como pretexto para prolongamento do diálogo e sugere uma evolução mental do monarca que o conduzirá a declarar que está totalmente possuído pelas labaredas da ambição e pronto a declarar sem ambiguidades o seu maior desejo, desvanecido já todo o resquício de vergonha: deseja que a multidão o adore de joelhos como um Deus. ${ }^{(17)}$ Desejo reiterado solenemente diante de Ambição a cujo arbítrio se submete e cujas exigências promete satisfazer: ser um servo fiel da glória, arredar do seu caminho, de forma implacável, quantos se lhe opuserem. Este domínio da Ambição sobre o tirano tem a sua tradução simbólica numa linguagem de estilo emblemático. Ambição coloca o seu trono ao lado do do monarca; este pede para ela lhe atar as mãos com nós apertados e lhe prender cadeias ao pescoço. ${ }^{(18)}$ Ambição parte levando consigo o coração de Nabucodonosor e face ao convite deste para que venha visitá-lo a sua casa, ou melhor, corrige Nabucodonosor, à casa dela, responde-lhe esta de forma subtil e engenhosa, patenteando um conceptismo tipicamente barro-

(16) "Cupido Iam regni leges inclytas tradam mei / In nostro regno lex prima est, nullus pudor / Secunda, nec hominem uereri, nec Deum,» - III, 2, 730-732.

(17) "Nabuc. Tanquam Deus / Cupio adorari supplici a turba genu» - III, 2, 752-3

(18) «Nabuc. Arctis Cupido deprecor nodis manus / Vinci, catenas necte ceruici tuas / His esse potius nexibus uinctum iuuat, / Quam liberato currere qua uelim gradu.» - III, 2, 783-6. 
co: «Virei, ou melhor, não virei, pois embora pareça afastar-me é aqui que permaneço. É esta a minha natureza. Geralmente estou mais onde menos pareço estar». (19)

O palácio de Soberba: A abertura de cena no acto II coloca a plateia perante um quadro alegórico representando o palácio de Soberba. Pelas personagens que habitam esse palácio, por duas didascálias na margem e pelo teor dos diálogos, facilmente se conclui que o dramaturgo deixou aqui fortes pretextos para um cenário tipicamente barroco, onde a acentuada carga simbólica anda a par com um esplendoroso fausto, de colorido variado e exótico, proveniente quer da indumentária identificadora de cada personagem quer de outros objectos que, por exigências da encenação ou por mero reforço da verosimilhança, figuravam em cena.

É o diabo quem faz as apresentações de Soberba como «domina mundi» (v. 212), servida por inúmeros criados em toda a terra. A cena exibe alguns dos mais ilustres, diferenciados certamente pelos seus trajes característicos e por outros adereços simbólicos. São eles Rómulo, "O ilustre fundador de Roma," Alcides, "O terror de toda a terra, domador de monstros», Nino, o mítico fundador de Nínive, e Senaqueribe, antepassado próximo de Nabucodonosor. Todos, com excepção de Nino, intervêm em cena professando solenemente o seu comprazimento pessoal em se submeterem ao poder de Soberba. Neste ambiente de completa submissão de todo o mundo às leis da Soberba, a presença de Daniel constitui-se como um elemento dissonante. É ele o porta-voz do poder divino que faz frente a uma Soberba com ânsias de poder absoluto. Soberba conta com os serviços de um Mago, representante dos poderes ocultos, cuja caracterização e actuação em cena se revelariam ricas de sugestão, dada a forma como nas suas falas revela confiança nos seus sortilégios. Assinale-se finalmente a presença dum carro

\footnotetext{
(19) "Cupido Veniam, imo non ueniam, nam gradum / Auferre licet hinc uidear, hic maneo tamen / Nostra isthaec est natura, saepe sum magis / Vbi minus esse uideor, iam felix mane.» - III, 2, 800-2.
} 
em cena, carro esse que Soberba, antes de se voltar em definitivo para a magia, tenta em vão por duas vezes, de acordo com as didascálias, fazer rodar de encontro a Daniel para o esmagar sob as rodas. (20)

Esta cena no início do acto II revela-se estruturante de toda a acção dramática, pressagiando os seus futuros desenvolvimentos. É patente o antagonismo de situação dramática entre esta cena e a cena final que marca o desenlace do drama. Em ambas é a ideia de triunfo que move a acção, nomeadamente através da presença do carro, elemento basilar tradicionalmente associado à expressão alegórica do triunfo. As pretensões falhadas da Soberba de esmagar Daniel, não conseguindo mover o carro, podem tomar-se, pelo ridículo que geram, um prenúncio do desfecho deste combate travado entre a Soberba e o poder divino, aqui representado por Daniel. A cena, entretanto, alimentar-se-á deste triunfo efémero, como o deixam antever as palavras de Daniel. "Parte agora, alegre e sorridente com o teu triunfo. Mas não será por muito tempo que sentirás o gosto de rir».(21) O palco vai animar-se com este confronto entre as trevas e o poder divino. Nabucodonosor deixar-se-á prender por Ambição, filha da Soberba, mas na obtenção do que mais ambicionava, verá o triunfo fugir-lhe no martírio dos três jovens.

O combate pela fé: A condenação à morte na fornalha ardente dos três jovens hebreus, companheiros de Daniel e favoritos de Nabucodonosor, por se recusarem a prestar honras divinas ao tirano, ocupa uma longa cena de duzentos e catorze versos. O interrogatório de Nabucodonosor, dividido entre a necessidade de fazer cumprir o seu édito e a profunda compaixão e simpatia que nutre pelos três jovens; a entrada em cena das alegorias da

(20) "Hic magicus et diabolus in rotas incumbentes mouere currum non potuerunt, quare illos Superbia summa cum indignatione a se reiecit. Abite etc»- BPE, cod. CVIII/2-7, fl. 64r $m g$; "Hic iterum conati sunt irruere, et currum incitare, sed omnis eorum conatus elusus est. Quapropter Superbia. O non ferendum» - Ibid. fl. $64 \mathrm{v} \mathrm{mg}$.

(21) «I. Perage mente quod agitas dudum tua / Sed non licebit diutius facto frui. / I nunc triumpho laetus et ridens tuo / Sed non licebit diutius risu frui» - II, 1, 370-3. 
Fé, da Esperança e da Constância para acompanharem e animarem os três jovens em momento de provação; a tentativa frustrada de Nabucodonosor de aniquilar as três mulheres, isto é, as figuras alegóricas acabadas de referir; o milagre da salvação miraculosa dos três jovens; o espanto de Nabucodonosor e a sua subsequente profissão de fé no Deus de Israel, explicam a duração desta cena central do drama.

A transposição deste episódio para o palco, pelo que o texto sugere, terá proporcionado à plateia uma cena bem decorada e movimentada, plena de artifício, numa conjugação de recursos sonoros e plásticos que, associados à declamação, deram expressão aos temas do heroísmo, da glória e do triunfo. O carácter prodigioso desta cena como que surge anunciado nas palavras da Fé:

«Hoje veremos com que prodígios a verdadeira fé é posta à prova».(22)

É a virtude heróica que aqui é posta à prova nos três jovens às mãos dum tirano que, baldados os seus esforços de os demover com palavras lisonjeiras e promessas de dádivas generosas, se encoleriza e ameaça com a crueldade do suplício. O prodígio encheria a cena. Constância, Esperança e Fé entrariam como personagens ex-machina, deixando os soldados paralisados de espanto ante um tirano encolerizado por não ver cumpridas as suas ordens. ${ }^{(23)}$ As três virtudes tomariam assento num trono cujo brilho e esplendor, de tão intensos, deixariam os soldados novamente confusos e inertes face às ordens que tinham de aniquilar aquelas mulheres. ${ }^{(24)}$ Como estaria representada a fornalha ardente? O texto sugere a sua proximidade, ao alcance verosímil do olhar das personagens, talvez trazendo para a

(22) "Fides Ne nominate mortem, hodie uidebitis / Quantis se uera prodigiis probet fides. - III, 4, 925-6.

(23) "Arripite, quid statis lenti satellites?» - III, 4, 913

(24) «Nabuc. O timidi, lenti, inertes, ignaui milites, / Quo fugitis? Mentes quis tantus terret timor? / An alto flammas creditis ueras iaci? / Ars magica solitis excitat lucem dolis. / Eia iterum ruite, ferte nec retro gradum. / Milites Heu quantus ambit lucidum splendor tronum? / Maiestas quanta fulminat contra minas?" - III, 4, 983-9. 
cena a ilusão do clarão das suas chamas. Nabucodonosor, em cena, dirige a fala aos três jovens na fornalha. ${ }^{(25)}$ O relato da salvação miraculosa é feito por dois mensageiros, em acção conjugada, sobre um fundo sonoro que associa o crepitar das chamas e o som harmonioso do hino de louvor entoado pelos jovens. Do anjo que deteve o avanço das chamas dentro da fornalha, referido pelos mensageiros como todo de luz, com um fulgor de fogo que feria os olhares, ${ }^{(26)}$ o texto não postula necessariamente a sua presença em cena.

Esta cena, que se situa no meio da representação, pode considerar-se uma cena fulcral pela articulação que evidencia com toda a acção dramática, tanto a anterior como a posterior. A recorrência da temática da magia nas palavras de Nabucodonosor, que vê truques de magia nos prodígios que imobilizam os seus soldados, ${ }^{(27)}$ não deixa de evocar os esforços baldados de Soberba de fazer avançar o carro para esmagar Daniel e o seu posterior recurso aos serviços dum mago. A evocação, pela Fé, da venda do coração à vã glória e a promessa da sua restituição, (28) além de aludir à anterior presença de Ambição em cena, antecipa já o desenlace, onde vemos a recondução de Nabucodonosor no poder associada à recuperação dum coração novo, que Esperança lhe dá de presente. (29)

Dos diálogos travados nesta cena repleta de som e cor, com destaque na parte final para a harmonia musical e o brilho esplendoroso que auréola as personagens ex-machina, realce-se o carácter gnómico em algumas fases desses diálogos, com máximas cujo conteúdo se articula com as correspondentes figuras alegóricas:

(25) «Sidrac, Misac, Abdenago, et tu quisquis es, / Tantam corusco lucem, qui uultu iacis, / Et frangis aciem, conspici, nec te sinis...» - III, 4, 1028-30.

(26) «Fulgore quartus igneo totus micat," - III, 4, 1005.

(27) "Ars magica solitis excitat lucem dolis.» - III, 4, 986.

(28) «Tu, cum cor dederis gloriae sic hodie tuum / Nequaquam nos ubi excipere possis, habes / Quod si reduci cor tibi tuum cupis," - III, 4, 1049-51

(29) «Fides Euolue tandem spes soror magnum sinum / Missumque caelo munus. Nab. O uere Deae / Caeleste donum, sumo iam sceptrum manu, / Regnare iam me posse securum puto. / Spes Quid tam laetaris cordis obtentu noui? / Nab. Nil corde maius optimo Reges habent." - V, 4, 1816-21. 
Nabuc - Quem és tu? Procurai algemas bem pesadas, clientes.

Fé _ - Não há cadeias que possam aprisionar a Fé.

Nabuc - Lançar-te-ão às chamas.

Fé _ - Brilharei ainda mais. A fé autêntica refulge muito mais nas chamas. ${ }^{(30)}$

$[\ldots]$

Nabuc - Que ela receie pois aquele a cujas mãos pode morrer.

Esperança - Quem é conduzido pela nossa mão não teme poder algum.

A esperança percorre caminhos penosos com muita alegria.(31)

$[\ldots]$

Fé _ - Vai, ó verdadeira e fiel descendência dos Patriarcas.

Precedidos pela Fé, nada vos é doloroso.

Constância - Vai, avança alegremente com passo firme por entre as chamas.

Comigo a seu lado, ninguém se deixa vencer pelos infortúnios.

Esperança - Avança. Ilustre estirpe de Abraão; ri-te das ameaças.

Ao lado da Esperança, todo o sofrimento se torna agradável.(32)

\section{Conclusão: Matriz jesuítica e estética barroca}

Ainda que o contexto codicológico nos não fornecesse inequívocas garantias da génese jesuítica deste drama, um conjunto de indicações dadas pelo texto far-nos-ia chegar igualmente à conclusão segura de que só

(30) «Nabuc. Quae tu? Catenas quaerite, clientes, graues. / Fides Nullis teneri uinculis fides potest. / Nabuc. Daberis in flammas praeceps. Fides splendebo magis / In flammis uera, clarius fulget Fides.» - III, 4, 927-930.

(31) «Nabuc. Quem igitur timeat, cuius intereat manu. / Spes Nullam horret, nostra quem manus ducit, manum, / Spes per difficiles laetior currit uias.» - III, 4, 937-9.

(32) "Fides I, uera ueterum, i, fidens progenies Patrum, / Antecedente, nihil est asperum, fide. / Constantia I, perge forti laeta per flammas gradu, / Me comite, nullis uincitur quisquam malis. / Spes I, clara proles Abrahae, i ridens minas, / Omnis, spe comite, redditur dulcis labor.» - III, 4, 998-1003 
poderíamos estar perante uma peça jesuítica, encenada com aparato para altura solene (início ou encerramento do ano lectivo, distribuição de prémios, visita de personalidade importante, etc.). O intuito pedagógico, como factor mobilizador das opções privilegiadas no domínio da poética, por demais evidente nos temas e tópicos implicados, testemunha claramente a favor dessa matriz jesuítica.

Esta dramatização, a pretexto do conhecido episódio bíblico da fornalha ardente, oferece-se ao fim e ao cabo como uma ilustração do lema da Companhia de Jesus, "Ad maiorem Dei gloriam», num ambiente de heroísmo que tem como pano de fundo um combate donde derivará logicamente o triunfo de uma das partes à custa da pesada humilhação da outra. Dentro deste esquema linear de que se alimenta a dramatização perpassa um espelho do príncipe. Na personagem Nabucodonosor podemos ver projectado o retrato do monarca absoluto cuja legitimidade dinástica não é posta em causa, mas sim o exercício do seu poder, a que são fixados limites. A cena dramática dá-nos dois modelos bem contrapostos do monarca: primeiro, o tirano pagão, a que se contrapõe, no desenlace, o monarca cristão. No primeiro tipo, temos um Nabucodonosor orgulhoso, sedento de glória, pronto a sacrificar tudo o que de mais precioso possui, a sua pessoa, simbolizada no seu coração. Nesta fase, em que o monarca anseia ser igualado aos deuses, o recurso às forças ocultas da magia, como forma de remover os obstáculos ao acesso ao supremo poder ou à sua manutenção, é a regra. A condição de tais monarcas, porém, como avisa repetidamente o texto, designadamente no coro IV, não os subtrai ao jogo cíclico das forças da fortuna que, na sua rotação cega, vai fazendo tombar no abismo quem antes guindara às maiores alturas. (33)

No Nabucodonosor da segunda fase, que passou por um processo de humilhação e que depois vemos reconduzido ao poder, o dramaturgo parece

(33) "Ardua quisquis tempora gemmis / Condis, et auro, sceptraque gestas, / Altoque sedes solio, cerne / Cerne labantes quomodo gressus / In tam lubrico tramite figas» - Chorus V, $1459-63$. 
ter tido o cuidado de deixar um conjunto de indicações que, contrapostas às do parágrafo anterior, remetem para uma condição qualitativamente diferente do monarca, como homem de poder. Já nos referimos à sua humildade, traduzida em cena com um exagero que se poderá mesmo classificar de barroco e que redunda, funcionalmente, na afirmação do poder divino. Aludi igualmente à profunda renitência em regressar ao poder, um tópico muito frequente nos Jesuítas, onde se dá expressão à consciência aguda dos perigos que espreitam quem detém o poder, o maior dos quais é o de o governante pretender que o adorem como um deus. A esta humildade e fastio pelo poder, junta-se a vergonha por ter despedaçado o seu coração, ao entregar-se à Ambição. Das indicações aqui deixadas sobre a nova condição de um soberano que, na intenção do dramaturgo, talvez possamos qualificar de cristão, a primeira tem a ver com um acto simbólico que se passa em palco, na cena final: Esperança, exortada pela sua irmã Fé, desdobra o seu grande manto e dá-lhe o presente enviado do céu: «um coração novo que nenhum ímpeto de Ambição poderá demover, mesmo que esta estenda os seus dardos ou as suas cadeias». (34) Com esse coração novo Nabucodonosor atinge nova condição como homem de poder. Subtrai-se ao jogo cego das vicissitudes da fortuna em que se vêem enredados os soberanos insensatos. Fé reconhece no Nabucodonosor regressado da penosa humilhação uma pessoa sensata, em condições de empunhar o ceptro, de se revestir do esplendor da púrpura e de, sem medo, subir ao trono, pois nenhum poder o precipitará de lá.(35) A outra indicação, porventura mais significativa da preocupação do dramaturgo em sugerir o perfil do soberano cristão, tem a ver com os limites do poder real. Estamos no final da peça, nos derradeiros versos da última cena, que deixam antever já a magnificente saída de cena, em cortejo festivo, ao estilo dos triunfos renascentistas. Não falta o

(34) "Spes Laetare potius dabimus cor nouum tibi / Quod nulla possit flectere uis cupidinis, / Seu tela, seu catenas intendat suas." - V, 4, 1811-3.

(35) "Ascende pulso iam regium tronum metu, / Iam nulla te uis inde praecipitem dabit." $-\mathrm{V}, 4,1828-9$. 
carro para simbolizar o triunfo, a par de outros motivos alegóricos e uma disposição ordenada dos figurantes, que desfilarão exibindo as têmporas enfeitadas de flores e empunhando ramos de palmeiras, ao som do canto triunfal constituído pelo coro V. ${ }^{(36)}$ Falta, porém, dar o devido castigo à Ambição e à Perfídia. A causa é de Nabucodonosor, mas este entrega-a à Fé, para que seja esta a decretar tal castigo, e, ao fazê-lo de bom grado, explicita as razões:

"Só tu conheces as insídias, só tu as poderás punir devidamente». (37)

Com esta concessão à Fé, Nabucodonosor deixa de si, em momento fulcral da situação dramática, pouco antes de o pano baixar, a imagem modelar do soberano sábio, consciente de que nem tudo lhe é lícito, capaz de auto-limitar-se ante o poder verdadeiramente soberano que é o poder divino, representado ali por Fé, personagem alegórica. Cabe à Fé julgar e punir, a mesma Fé que, em situação dramática bem diferente, fora acusada por Nabucodonosor de ensinar os súbditos a desprezar as ordens dos reis e que na altura lhe respondera:

«- Precisamente quando os reis ordenam o que é contrário a Deus»(38)

É recorrente na dramaturgia jesuítica a emergência deste modelo de governante desapegado do poder, preferindo ao bulício da corte a rudeza e o sossego da vida humilde, em cuja construção convergem, como neste drama, uma série de topoi hauridos dos textos clássicos seleccionados para leitura nas diversas classes. Não é difícil reconhecer nesse modelo, incarnado

(36) "At nunc feramus regiam ad domum gradum / Laeti thriumpho, floribus cincti comas / Ornate, palmas capite, iam regnet Fides, / Fides thriumphet, floreat Fides Fides / Det iura mundo, nemo non colat Fidem. / Praei Michael magne defensor sacrae / Custosque Fidei; ducite currum nobiles / Magnique Vates: laetos uos fundite cantus» - V, 4, 1871-1878.

(37) «Nab. Trado libenter, sola tu nosti dolos / Punire sola tu dolos poteris satis.» - V, 4, $1849-50$.

(38) «Fides Cum nempe Reges contraria iubent Deo.» - III, 4, 934. 
neste Nabucodonosor restituído ao poder, a corrente do anti-maquiavelismo cristão, em que, entre outros nomes, se inclui o do português Jerónimo Osório, teve também como paladinos eminentes jesuítas, de que se destacam Pedro Ribadeneira, Juan Mariana e Giovanni Botero. Foi a partir da obra deste último, Della ragion di stato (Veneza, 1589), que ganhou corpo entre os doutrinadores jesuítas a teoria da razão de estado cristã, caracterizada como "a razão de estado ad maiorem Dei gloriam, que exprime a perfeita harmonia entre os ensinamentos da fé e as exigências inescusáveis do governo dos povos proclamada pela Razão».(39)

Os exercícios espirituais: Outro elemento de matriz jesuítica, facilmente perceptível neste tipo de dramatização do episódio bíblico é a dinâmica dos Exercícios Espirituais que, da mesma forma que marcava singularmente a vida de cada jesuíta, cremos que condicionou aqui de forma ineludível o trabalho do dramaturgo.

É sabido que os Exercícios Espirituais consistiam basicamente numa contemplação interior avivada por técnicas que estimulavam a imaginação do exercitante na recriação de cenários e de situações onde ele próprio se inseria. No caso do presente drama, com a apropriação singular do episódio bíblico nele testemunhada, a plateia era colocada a contemplar em palco uma realidade espiritual a que não é alheia qualquer pessoa. Ainda que não sejamos monarcas absolutos, não estamos ao abrigo de nos confrontarmos, em grande ou pequena escala, com os assaltos ardilosos do orgulho ou da ambição. A cena em que Nabucodonosor é assaltado pela Ambição e o vemos, após um longo e bem imaginado processo de cedências, totalmente rendido, implorando ao vício alegorizado que lhe ate as mãos com nós bem apertados e lhe prenda cadeias ao pescoço, essa cena soa-nos como a compositio loci em que o exercitante era convidado a associar imaginativamente uma situação de pecado a uma situação física como a de estar

(39) NAIR DE NAZARÉ DE CASTRO SOARES, O príncipe ideal no século XVI e a obra de D. Jerónimo Osório, INIC, Coimbra, 1994, p. 203-204. 
numa prisão. (40) A cena do combate pela fé, onde os três jovens recebem o auxílio das três virtudes remete-nos igualmente para outro prelúdio dos Exercícios Espirituais em que o exercitando se contempla a si próprio diante da Corte Celeste e é convidado a ver com força imaginativa como todos os santos intercedem por ele. ${ }^{(41)}$ O binarismo que referi na construção de alguns diálogos onde duas personagens se desdobram em considerações sobre a mesma questão (a cena dos dois sátrapas é o exemplo mais flagrante), parece remeter igualmente para a técnica da exercitação inaciana. Neste caso concreto, sou tentado a ver a génese deste binarismo, tão em voga neste drama, no exercício congeminado por Santo Inácio, das três classes de homens reflectindo sobre o destino a dar a uma grande soma de dinheiro adquirida indevidamente. Aqui cada classe agrupava dois homens. Esta divisão de cada classe em dois facilitaria o desenvolvimento imaginativo de diálogos criados para o efeito, colocando o exercitando mais como observador e não tanto como juiz de si próprio. ${ }^{(42)}$ O binarismo dos diálogos tal como nos surge na referida cena dos dois sátrapas favorece, em benefício da plateia, uma melhor observação da situação dramática, segundo os três pontos da dinâmica contemplativa proposta por S. Inácio: observar as pessoas, escutar o que dizem, ver o que fazem.

\section{Estética barroca}

Pelo tipo de elocutio, testemunhada directamente no texto e pelo aspecto duma encenação que conjecturamos como magnificente, a estética subjacente à imitatio do dramaturgo parece enquadrar-se claramente no movimento do Barroco. Comecemos pela elocutio.

(40) HEINRICH PFEIFFER, S. J., "La radice spirituale dell'attività teatrale della Compagnia di Gesù negli 'esercizi spirituali' di San'Ignazio", in I Gesuiti e i primordi del teatro barrocco in Europa. XVIII Convegno Internazionale del Centro Studi sul Teatro Medievale e Rinascimentale (Roma, 26-30 de Outubro de 1994) Roma, Torre d'Orfeo Editrice, 1995, p. 32.

(41) Cf. loc. cit.

(42) Ibid. pp. 34-36. 
A estratégia de persuasão montada em palco, numa conjugação forte e massiva de elementos de vária ordem, ultrapassa o domínio da elocutio. Esta enquadra-se nessa funcionalidade persuasiva através de um jogo recorrente de figuras de estilo que conferem ao discurso um tom épico e emotivo. Merecem realce as figuras de repetição, de efeito amplificador, não apenas de adjectivos, substantivos e verbos, ${ }^{(43)}$ geralmente em grupos de três, mas também de expressões de horror ou de indignação, de juras e de orações inteiras na figura do isocólon trimembre. ${ }^{(44)}$ A esta repetição acumulante, que funciona no sentido de acentuar a evidência do que se passa em cena, há que acentuar igualmente a recorrência muito frequente da interrogação e da exclamação, numa clara estratégia de acumular para impressionar. ${ }^{(45)}$

Outro aspecto da elocutio digno de menção é o recurso frequente à simetria, muito perceptível nas fases mais vivas dos diálogos, onde a alternância das falas se sucede com rapidez. Isto ocorre sobretudo nos diálogos antinómicos, muito característicos deste drama, onde o paralelismo antitético une algumas vezes na figura do quiasmo dois versos de falas diferentes. (46) Nas tiradas mais longas, o tom declamatório vive sobretudo da anáfora ${ }^{(47)}$, muitas vezes combinada com a metáfora e a perífrase, com efeitos de engrandecimento e de sublimação. ${ }^{(48)}$

(43) Vejam-se só alguns exemplos dos muitos que marcam o texto. a) de adjectivos: "Finire uitam hic liceat, impios Lares, / Infandos postes, funestam intrabo domum.» - V, 2, 1608-9; b) de substantivos: "Cupido Minare poenas horrificas, ferrum, feras / Flammas, catenas, pectines, diras neces / Et quae non tantis uincetur uirtus malis?» - III, 2, 764-6; c) de verbos: "Satrapae Agnosco, fateor praedico, ad pedes cado, / Adoro supplex, pronus inclino caput, / Viuat, diuque uiuat, regnet, imperet / Debellet hostes, proterat, calcet suos.» - IV, 2, 1187-1190.

(44) «Ille est, trisulcas mittit qui manu faces, / Qui uersat orbis uastos immensi globos / Qui sceptra sponte donat, et adimit sua. »- V, 2, 1570-2.

(45) Um exemplo de acumulação de exclamações. "O summa gentis caecitas mortalium! / O error ingens! O tenebrosum genus!» - II, 2, 401-2. Acumulação de interrogações: "Quo enim potest sanari qui sic non potest? / Quid expectas? Quid differs exitium pater? / Quid raptas cogit toties flammas ponere ? / Quid uincit animum? Quid ligat iratas manus? »- II, 2, 486-90.

(46) Vejam-se estes dois casos típicos: «Dan. Numen recusas facere quod summum imperat? / Nab. Numen recuso facere quod summum uetat.» - V, 2, 1612-3; "Habere talem patrem est regno charius. / Nabuc. Habere talem natum est regno pulchrius, - - V, 4, 1739-40.

(47) «Iam non precabor, iam non obsistam Deo,» - IV, 1, 1121.

(48) "Como neste caso, para engrandecer a majestade divina: "Princ. Adoro Numen, Daniel et colo tuum / Ille est, trisulcas mittit qui manu faces, / Qui uersat orbis uastos immensi globos / Qui sceptra sponte donat, et adimit sua. " - V, 2, 1569-72. 
A encenação: A ausência quase total de didascálias impossibilita certezas inequívocas sobre uma encenação que, apenas com base em pistas advindas do texto, se crê ter sido de uma magnificência esmagadora, concedendo grande privilégio ao aspecto visual. Comecemos pelo vestuário. O tipo de personagens que integra a acção dramática fornece amplos pretextos para colorir a cena de requinte, pela variedade de trajes em personagens de condição e proveniência diversa. Pensemos em Nabucodonosor e na sua corte de sátrapas, em Vilmerodaque, seu filho, no profeta Daniel e nos três jovens hebreus. Já conjecturámos como a corte da Soberba, rodeada de vassalos tão ilustres (Senaqueribe, Hércules, Rómulo, Nino...) se deveria impor com uma decoração soberba.

O recurso a técnicas de persuasão extra-racional é um dos aspectos a salientar aqui. Ele tem a ver essencialmente com as personagens de índole alegórica: de um lado a Soberba, a Ambição e a Perfídia, a que podemos associar também o Mago; do outro, a Fé, a Esperança e a Constância, às quais se vem juntar depois o Anjo. Afigura-se-nos plausível conjecturar que na caracterização destas personagens houve um claro propósito de construir um espectáculo total por integração de todas as artes, exagerando as cores negativas de umas e realçando o brilho e o esplendor de outras. Esta estratégia de recorrer à utilização de elementos plásticos que logrem a atracção dos sentidos, favorecendo a acção directa de Deus, segue fins de natureza propagandística e não deixa de se inserir na dinâmica dos Exercícios Espirituais. (49)

Embora o tema hagiográfico, à primeira vista, se preste melhor a um tipo de teatro propagandístico com pretensões de responder a situações concretas, esta dramatização dos capítulos iniciais do Livro de Daniel parece-nos susceptível de enquadrar-se perfeitamente nesse tipo de teatro. Se é esta a tragédia noticiada na Sinopse de Franco como tendo sido representada em

(49) Sobre a utilização dum estilo pictórico por parte do barroco como meio de persuasão extra-racional cf. JOSÉ-ANTÓNIO MARAVALL, "Objectifs sócio-politiques de l'emploi de moyens visuels", Baroque VII (1974), pp. 111-119. 
1576,(50) lembremo-nos de que estamos em plena época de lutas religiosas, vistas do lado católico como lutas contra a heresia. Os acontecimentos recentes em França haviam dado um pungente espectáculo. A tristemente célebre matança de S. Bartolomeu foi tema privilegiado na exercitação escolar jesuítica. O mesmo códice que contém o texto desta tragédia contém igualmente um número razoável de composições poéticas alusivas ao acontecimento. ${ }^{(51)} \mathrm{Na}$ altura, a afirmação da Igreja Católica passava pela aplicação dos decretos do Concílio de Trento, com a ajuda imprescindível do poder temporal. No papel dramático de Daniel enquanto profeta do verdadeiro Deus, conselheiro político, assistente e consolador do povo hebreu, é legítimo ver projectada uma espécie de desejada aliança da Igreja Católica com as monarquias absolutistas, num esforço de catequização maciça visando a adesão ideológica uniforme e ortodoxa da grande massa da população. Assim se conseguiria com eficácia esmagar de forma humilhante a heresia e exaltar em seu triunfo a santa Fé católica, ad maiorem Dei gloriam.

(50) A notícia é a seguinte: "Mense Maio in scenam data tragoedia Nabucho, spectatores morata horas quinque: mirifice recreatus Cardinalis iucundo spectaculo». Cf. ANTÓNIO FRANCO, Synopsis Annalium Societatis Iesu in Lusitania ab anno 1540 usque ad annum 1725 . AugustaeVindelicorum et Graecii, 1726, p. 110, n ${ }^{\circ} 14$.

(51) Eis os títulos de alguns desses poemas: "De caede haereticorum» - fls. 58v, 59r-v; "Haeretici descriptio" - fl. 59v; "In Petrum Ramum in Sequanum demersum» - fls. 59v-60r. 
(Página deixada propositadamente em branco) 


\section{Série}

\section{Documentos}

Imprensa da Universidade de Coimbra

Coimbra University Press

2006

- $\mathrm{U}$

C • 